ORIGINAL PAPERS

劷 文

(51)

\section{1. 緒 言}

さきに揚水用小型エア，リフトホホンプの性能につい ては報告し1》，性能推定ならびに設計に対する基礎的検 討を行った。本報においては各種の液体を使用した場合 Кエア，リフトの性能が如何に变化するかをしらべると とるに，特殊な液体に対する実用上の参考资料を与える ことを目的とする。

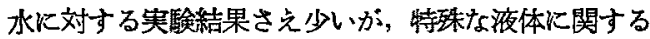
報告は筆者の知る限りに挌いては看とんどない。しかし 二相流の研究としては㹂型扰よび横型の反応管の理論と

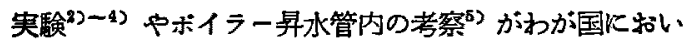
て子行われて扣り，外国林いてる2，3発表されてい
るので，必ずしあエフ，リフト，ポンブと同一条件て性 ないが参考となる。

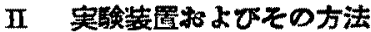

実験装置は前報と同様であって，小型空気生縮機から の圧縮空気をノズル型流量計に通してのちエア，リフト 管下端の吹出部へ送る。揚液量は一定時間の昷を科量し て求める。空気吹出部は上向き学一孔で前報と同様䄪外 径 $10 \mathrm{~mm}$ の の銅バイブを用いた。性能曲線に示すときに

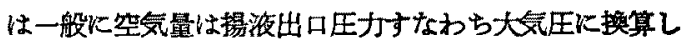
て容積で示し，液量す測定重量を密度でわって容積とし て表わしてある。たた固体粒の混合したときは毎回密度

Table 1 Air Lift Pipes for the Experiment.

\begin{tabular}{ccc} 
Material & $\begin{array}{c}\text { Pipe Dia. } d \\
(\mathrm{~mm} \phi)\end{array}$ & $\begin{array}{c}\text { Pipe Length } \\
\text { I (mm) }\end{array}$ \\
\hline Steel & 18.2 & -1050 \\
$"$ & 21.0 & 1050 \\
$"$ & 22.1 & 1065 \\
Glass & 12.5 & 1050 \\
$"$ & 14 & 1050 \\
$"$ & 14 & 1960 \\
$"$ & 18 & 1350 \\
" & 19 & 1050
\end{tabular}

Liquids for the Experiment

Water, Muddy Water, Sandy Water

Water, Light Oil, Spindle Oil, Ammonium Sulphate

Water, Light Oil, Spindle Oil, Ammonium Sulphate

Water, Light Oil, Spindle Oil

Water, Spindle OiI

Water, Spindle Oil

Water, Soap Suds,

Water, Spindle Oil

Table 2 Experimental Liquids and its Characteristics

\begin{tabular}{|c|c|c|c|c|}
\hline Liquid & $\begin{array}{c}\text { Density } \rho \\
(\mathrm{g} / \mathrm{CC})\end{array}$ & $\begin{array}{l}\text { Surface Tension } \\
\text { (dyne/cm) }\end{array}$ & $\underset{(\mathrm{g} / \mathrm{cm} \cdot \mathrm{s})}{\text { Static Viscosity } \mu}$ & Remarks \\
\hline Water & 1.00 & $74\left(9^{\circ} \mathrm{C}\right)$ & $0.013\left(10^{\circ} \mathrm{C}\right)$ & \\
\hline Soap Suds & 1.00 & $32\left(9^{\circ} \mathrm{C}\right)$ & $0.015\left(13^{\circ} \mathrm{C}\right)$ & Soap Concentration $1.7 \mathrm{~g} / l$ \\
\hline Light Oil & $0.83\left(22^{\circ} \mathrm{C}\right)$ & - & $\left\{\begin{array}{l}0.046\left(20^{\circ} \mathrm{C}\right) \\
0.082\left(11^{\circ} \mathrm{C}\right)\end{array}\right.$ & \\
\hline Spindle On & $0.91\left(10^{\circ} \mathrm{C}\right)$ & $36\left(9^{\circ} \mathrm{C}\right)$ & $\begin{cases}0.35 & \left(9^{\circ} \mathrm{C}\right) \\
0.24 & \left(18^{\circ} \mathrm{C}\right)\end{cases}$ & \\
\hline $\begin{array}{l}\text { Ammonium } \\
\text { Sulphate }\end{array}$ & 1.12 & $79\left(15^{\circ} \mathrm{C}\right)$ & $0.013\left(28^{\circ} \mathrm{C}\right)$ & Ammonium Sulphate $0.25 \mathrm{~kg} / \mathrm{l}$ \\
\hline Solution & 1.21 & $81\left(15^{\circ} \mathrm{C}\right)$ & $0.017\left(28^{\circ} \mathrm{C}\right)$ & $0.46 \mathrm{~kg} / l$ \\
\hline $\begin{array}{l}\text { Wood Powder } \\
\text { Solution }\end{array}$ & $0.98 \sim$ & {$\left[57\left(10^{\circ} \mathrm{C}\right)\right]$} & - & Wood Powder $[0.1 \mathrm{~kg} / l]$ \\
\hline Muddy Water & $\left\{\begin{array}{l}1.10 \\
1.25\end{array}\right.$ & {$\left[61\left(10^{\circ} \mathrm{C}\right)\right\}$} & $\begin{array}{l}{\left[0.012\left(20^{\circ} \mathrm{C}\right)\right]} \\
{\left[0.016\left(20^{\circ} \mathrm{C}\right)\right]}\end{array}$ & Clay "Kibushi" " \\
\hline Sandy Water & $1.1-1.3$ & - & - & Sand $90 \%$ Residue $=0.53 \mathrm{~mm} \%$ \\
\hline
\end{tabular}

Note: [ ] is an unreliable value, 
が異なり容屓で示すのに困難を感したので重量で示して ある。使用した揚液管は Table 1 のとく直径 $20 \mathrm{~mm}$ 申前後で，長さす I m 余りで直径の50倍程度をとって ある。管としては鉄管およびガラス管を用いた。使用液 としては基本となる水の他に Table 2 に示すような種類 を用い，その物理的性質す同表に示してある。これらの 内硫安母液と泥水打よひ砂水は固体粒を含んだ三相流と

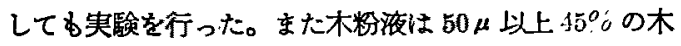

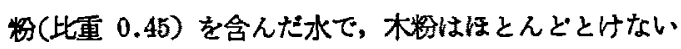

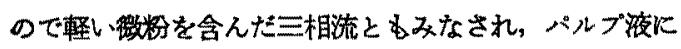
似た様相を呈するるのである。油類は各種の方法で粘性 を剆定したが，使用前後では，ほとんど粘性に差がなか った。

\section{III 実歇結果}

\section{1. 表面張力の影整}

液の比重や粘性が余りかわらなくて表面張力のみが水

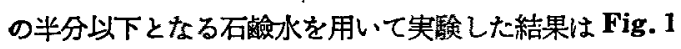
のガラス管で浸水率 $\sigma=0.4$ の場合のように㑮かの性能 向上がみられるが，問題にするはどではなく央用にされ る範囲では表面張力の影瑟は無視してよい。ただし安定 した泡立らが生じてくるとむはや密度の概念も全然かわ り簡単には諭しられなくなる。

\section{2. 苫性の影警}

粘性の影響は管壁における摩擦と二相流の内部粘性に よるSlip (相対速度)にあらわれてくる。この内管壁摩 絷の方は液の粘性怯同一であ管壁の粗さがかかれば变化 ナるから，その影響だけを検討したのが前報”にるある が, Fig. 1 Kおける鉄管 $(\sigma=0.5)$ の場合は, 普通のる のとそれを酸ではなはだしく㢁蝕させたすのとを比較し てある。腐飭したるのは最適流量附近までは異常を示さ ないか，最大流量近くから性能が低下しており，管摩擦 が大流量で不利なことを示している。ここに屑蝕した管 は直径が变化しているとる考えられるが，この場合の結 果を管径の变化のみによると仮定すると約 $1 \mathrm{~mm}$ 程度の 直径の緶少があったことになり，常識炕反するようであ る。またガラス管と鉄管の差す欧めて㛟討してみたが， 水のときは少しく性能㦈が出るのに対し，粘性の大き い油類では差は一層小さく，管壁の粗さの影饗がいずれ てしてる粘性の影帮に比して小さくはとんど無視しらる ことを示している。

次に粘性の大きく異なる水, 軽油和よびスピンドル油 飞よる結果を比較してみると Fig. 2,3,4 の例の通りで

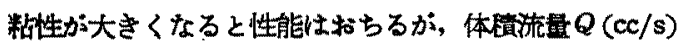
で比较すると軽油恃水汇比し約 8割位の揚液量となり， 管径の小さいるのでは更に少しく低下する頑向にある。

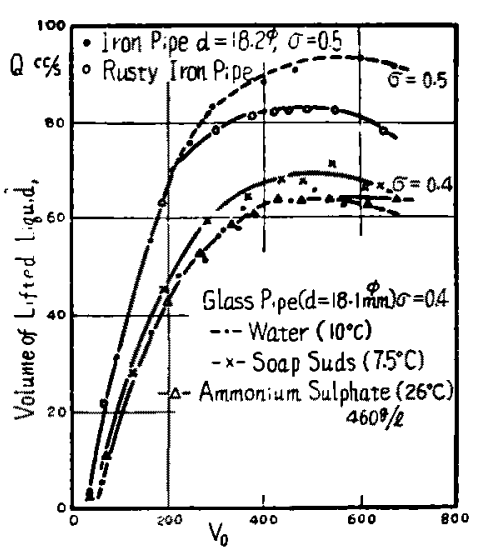

Air Volune at Atmospheric Pressure,

Fig. 1 Characteristics of Air Lift Pumps.

しかしこの值は最大液量附近のことで，小流量ではこの 液量比は 1 亿近つき，場合によると粘性の大なる方が性 能のよい所るある。またig.2では最大液量以上の大き い空気量において浸水率のが大きくなるとやはりこの液 量比は 1 に近ついている。スビンドル油蛙大最量附近 では水の約与割の液量を示している。エフ，リフトボ ンプとしては最大液量からその半分位の最適液量 (効率 最大) 附近までが一番使われる所であるが，その附近で はこの液量比が最低を示すわけで，この辺りの液量比を 液の静粘性䌽数に対して示してみると，Fig.5に示すこ そく次式が大体成立している。

$$
Q / Q_{0}=\left(\mu / \mu_{0}\right)^{-0.25}
$$

ただし $\mu$ の範国は 0.01 0.4 g/cm.sec (poise) のと きである。

効率に対する粘性の影䭗はその一例を Fig. 3 に示し てあるが，一般に粘性が大きくなると效率性若干低下し ている。油類は比重す水々異なるのでその影替む入って いるわけであるか，比重差は粘性の相違にくらべれば小 さくて後であのべるように無視できるであろう。

次に性能曲線に対するその他の 2,3 の傾向を列記す ると

1. 鋼管のときはガラス管に比し，液舅比の浸水率や 空気量化よる变化が少い。

2. 漫水率が大きくなると水に対する液量比は堌加し 水淁近する。

3. 管長と管得の比 $l / d$ が大きいときは液量比は减し

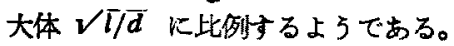

\section{3. 此重影吸}

他の物理特性が同しで比重のみが大きく变化した液は 得られにくいので，実用的な意味をかねて硫安母液と木 


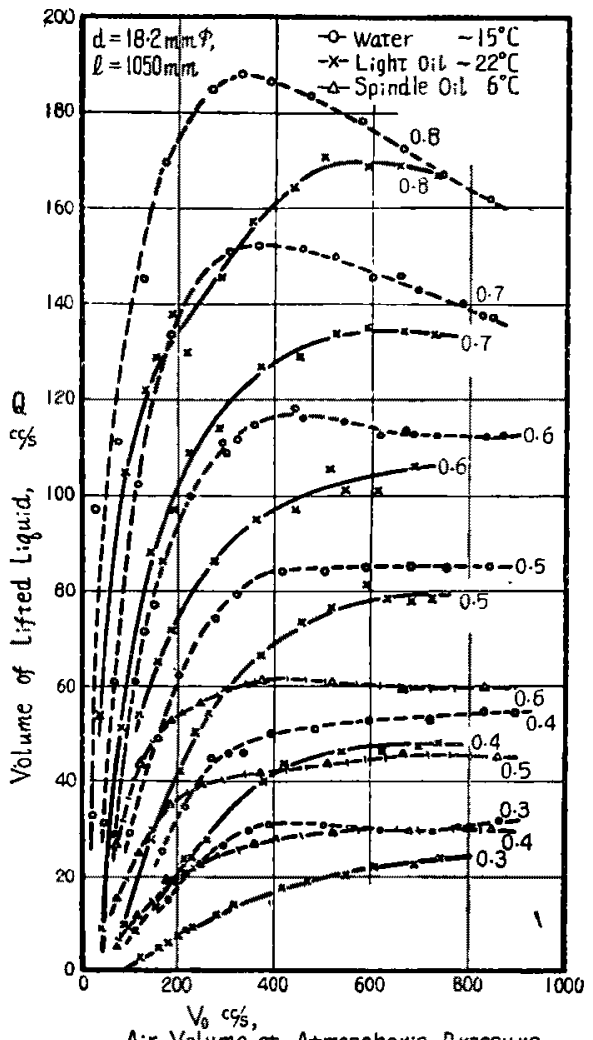

Air Volume at Atmospheric Pressure,

Fig. 2 Characteristics of a Steel Pipe. (Effect of Viscosity)

節粘土を含んだ淐水を用いた。いずれす表面 張力と粘性は水と余り変らず, 比重が 1.2 位 まで変化する。測定結果の一例は Fig. 6 と Fig. 7 に示す通りで，ほとんと水と变らな い。ただし洰水で比重が1.25のときは粘性が やや增加するようで大流量にて性能低下し， 小流量に抹いて向上している。濃い泥水はン オロジー的な粘性を示し簡単には論しられな くなるである5。要するにこれらの結果より 少くとあ此重 1.2 位までは揚液量を体棈で表 わせば, 水々性能上の差異を生しないといえ

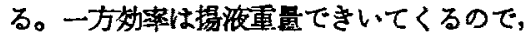
比重が增すとさしろ效率向上を示す傾问にあ る。

\section{4. その他の特殊例}

a. 固体絃を含む場合（三相浾）液中に含ま机 る固体䊀子が小さくて愁㷎洨が安定なときは液としてす あうかえるか，固体の沈降速度が早くて固液間炕相対速 度がかなりみとめられるときは趣がかかってくる。たと

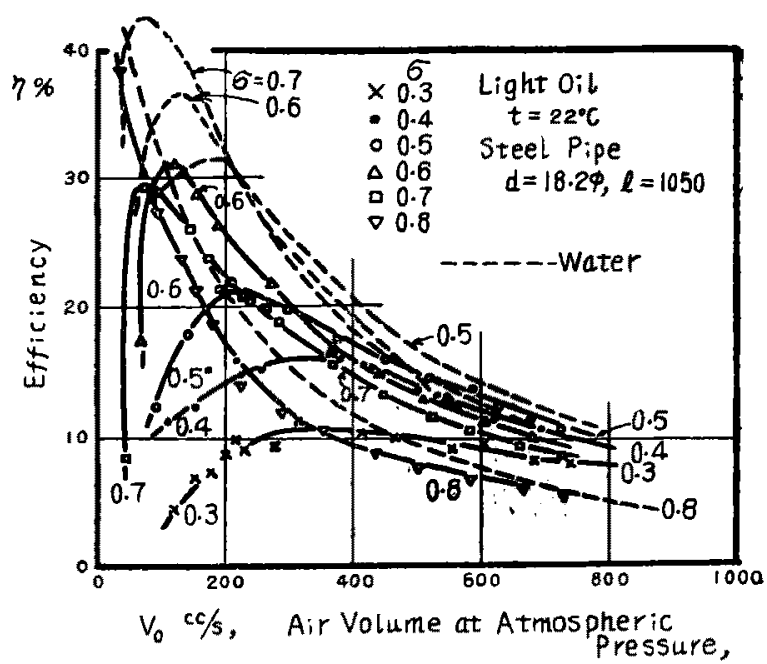

Fig. 3 Efficiency of a Steel Pipe. (Corresponding to Fig. 2)

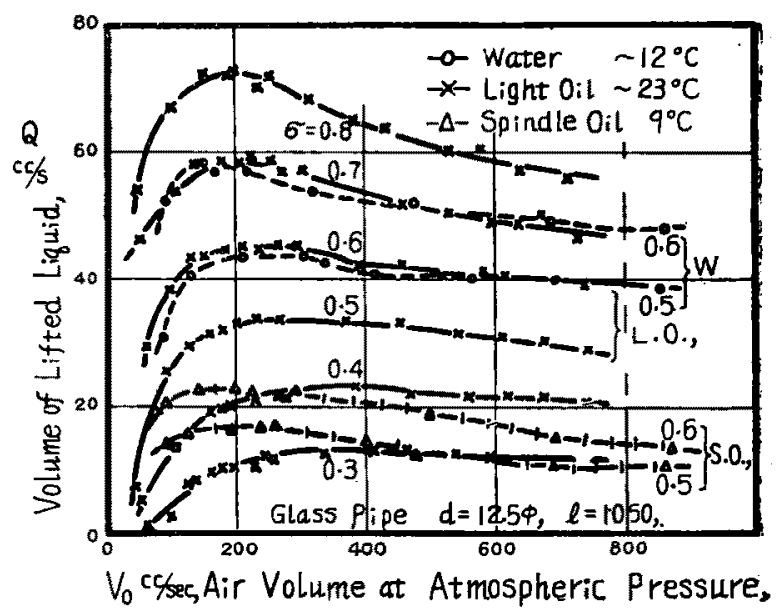

Fig. 4 Characteristics of a Glass Pipe. (Effect of Viscosity)

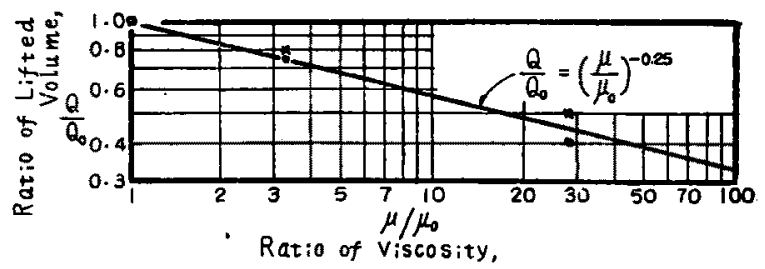

Fig. 5 Effect of Viscosity.

えば Fig. 6 の硫安母液が過飽和となり，碳安の結唱を 含さよらになったとき（実際の工場における探業は半分 位結晶を含む)や，Fig. 7 て䂗粒を含んだ水の場合がこ れに当る。すなわち一般に性能ははなは岋しく低下し 

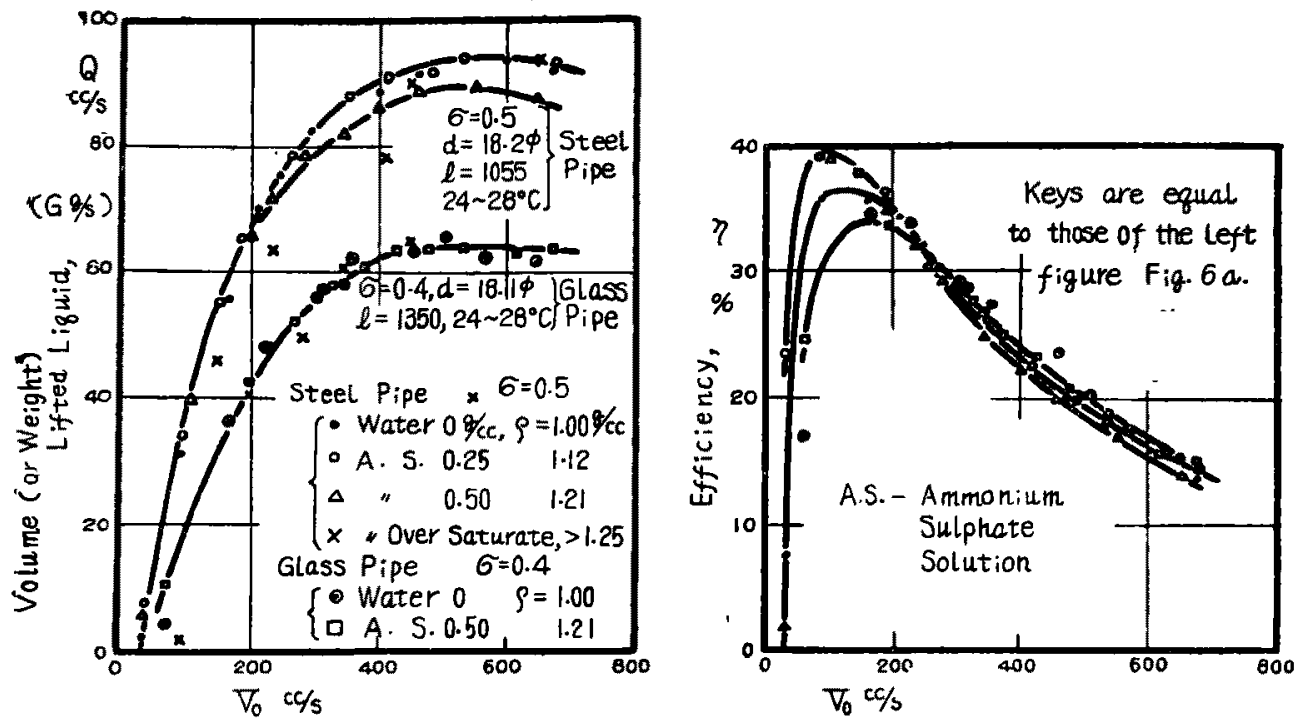

Air Volume at Atmospheric Pressure,

Fig. 6 Characteristies for Ammonium Sulphate Solution.

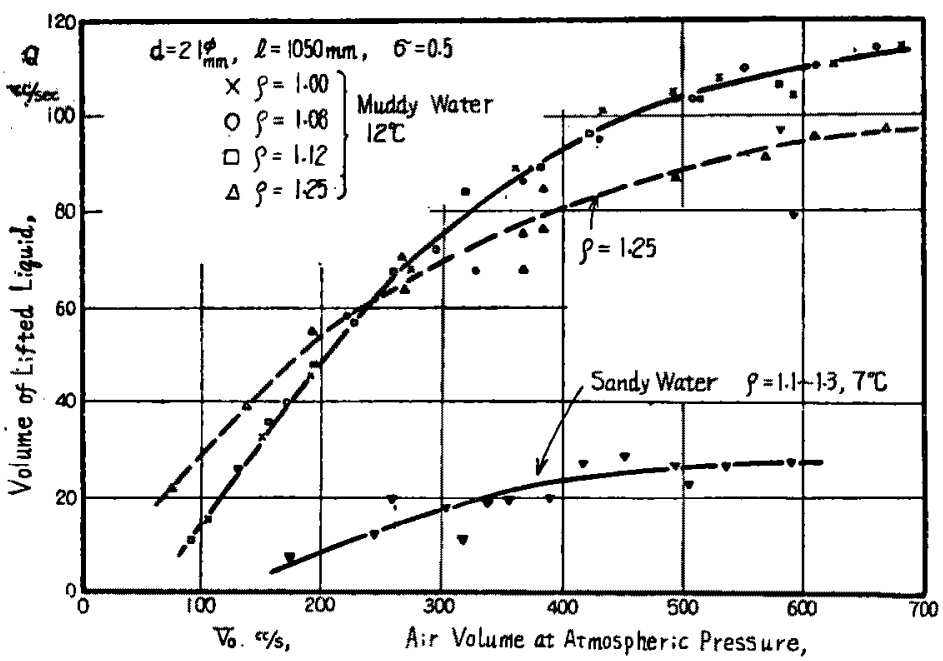

Fig. 7 Characteristics for Muddy Water and Sandy Water
ずそれ以上になると大流宜で性能 低下をを来す。さらに多量に木粉を含 さとドロドロとなり,すぐ林が沈 澱するよらになるが，大体㴰度 $10 \%$ 以上液比重0.95以下のときには固体 粒を含むときと同様にはなはだしく 性能低下をきたす。また瀦度 $10 \%$ 上 上のとき恃レオロジ的性啠が㩆替と なり，単純な粘性の变化とる考えら れない。な打粘性の項でるのへたこ とく濃度 3〜 7\%の木粉液では小流 量飞就いて水上り却って性能方向上 している。

\section{IV 扂} 特殊な場合を除いてははとんと水 の場合の性能と同しであることがわかったの、で, 改めて 水に対する $2 ， 3$ の検討を行ってみる。

管中で気体と液体とは相対速度 (Slip) をるって流れ てょり, その平均的な値は Hold up からる求められる $か^{22}$, 瞬間的な液の流速を求めるために管径 $21 \mathrm{~mm} \phi$, 管長さ $3720 \mathrm{~mm}$ の揚水管の上, 中, 下 3 ケ所（おのおの $1760 \mathrm{~mm}$ 宛の間隔）に針状電極を対向設置し，その間 に $100 \mathrm{~V}$ 交流を与光，下方 Foot Piece 部上り瞬間的に

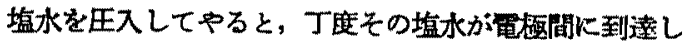
たとき電流が流れる。これを䉓磁オッシロにとってタイ ム,・ークとの対照から電極間を流れる所要時間が求主 
り，液流速 $v_{w}$ がえられる。したがって湓量Qから液の

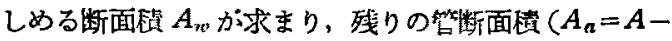
$\left.A_{w}\right)$ を空気が洗れることになるので，その洗䔔 $v_{n}$ とさ

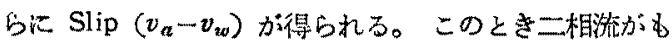
し，完全にピストン状に交瓦に管中を上最するとす机は Slip はなく $v_{n}=v_{w}$ となる。しかし実測の結果ではSlip は大体空気量とともに增㓜し，最大液量附近まででは 1 $\mathrm{m} / \mathrm{s}$ 程度で, 最適点附近で $0.5 \mathrm{~m} / \mathrm{s}$ 以下になるとい5 結果を得た。实驗回数が少いので確定的なことは言えな

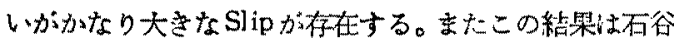
氏占の值にも近いので，妥当なるのと考える。ての湘定

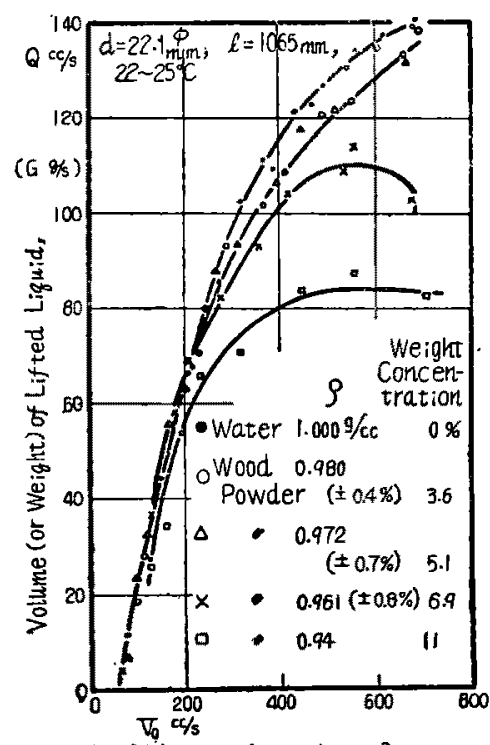

Air Volume at Atmospheric Pressure,

Fig. 8 Characteristics for Wood Powder Water.
例を Table 3 亿示す。更に揚水管を水平にした場合につ いてす求めてみたが，直立管と余り避わ植を示し，空 気の浔力のみか： Slip の主因であるとはいえないことが えかった。

次に液のすって出る運動エネルギをこれより算出して みると供給ェネルギの1\%程度以下の小さいるのとなり その回収は意味の少いことがわかる。 これは出口搪がり 角 $4^{\circ}$ おで $8^{\circ}$ の抝がり管を出口にるった掦水実験の結 果からす実証さ机なが，执がり出口は直管よりる性能が 低下し前報”に括ける段付管の結果が悪かったことるう なつける。

さてここに液と気体が slip なしで管中を上昇すると 仮定して，平均上刑速度を最適点（効率最大）乙最大液 量点（最適点の約 2 倍の液量）とで過去のデータも参照 して各種の管について求めてみると，浸水率や管径汇は 余り影䜾されず大体一定とみられる。すなわち最適点で $1 \mathrm{~m} / \mathrm{s}$ 以下, 最大点で $2 \mathrm{~m} / \mathrm{s}$ 以下となっている。一方気 液比は前報》や本報の結果から推定できるから, 所要液 量に対する管径および必要空気量の榆討や推定がこの值 からる可能である。しかして slip による損失と管烀擦 による挰失と㤋分離することが因奞であるが，空気速度

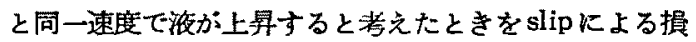
失がない場合と仮定して計算してみると，最大液量以上 では管挈擦の損失が slip 摃失に比し大きいといえる。

さらにガラス管の埸合について外部より写真撮影 (1) 200 秒) をして観察した結果では一様に気液が混合して 流れるのではなく，交互にビストン状上年をしているの がみとめられた。しかし管壁に浻ってはかなりの slipが みとめられたので，全体として slip しながら交互に気液 が上昇するのが，この程度の二相流の流れ機椣のようで

Table 3 Liquid (Measured) and Air (Calculated) Velocity by the Salt Water Method, $d=21.0 \mathrm{~mm} \phi, l=3720 \mathrm{~mm}, A=A_{a}+A_{w}=3.47 \mathrm{~cm}^{2}$

\begin{tabular}{|c|c|c|c|c|c|c|c|c|c|c|c|}
\hline No. & $\sigma$ & $\begin{array}{c}V_{0} \\
\mathrm{cc} / \mathrm{s}\end{array}$ & $\underset{c c / s}{Q}$ & $\eta \%$ & $v_{10} \mathrm{~cm} / \mathrm{s}$ & $A_{s} \mathrm{~cm}^{2}$ & $\mathrm{v}_{\boldsymbol{n}} / \mathrm{s}$ & $A_{a} \mathrm{~cm}^{2}$ & $5 \mathrm{~cm} / \mathrm{s}$ & $\varphi=A_{1 v} / A$ & $\varphi^{\prime}$ \\
\hline $\begin{array}{l}8-1 \\
8-2 \\
8-3\end{array}$ & $\begin{array}{l}0.8 \\
" f \\
" 1\end{array}$ & $\begin{array}{r}552 \\
397 \\
82\end{array}$ & $\begin{array}{l}307 \\
300 \\
159\end{array}$ & $\begin{array}{l}16 \\
22 \\
55\end{array}$ & $\begin{array}{r}163 \\
170 \\
63\end{array}$ & $\begin{array}{l}1.88 \\
1.77 \\
2.58\end{array}$ & $\begin{array}{r}347 \\
233 \\
92\end{array}$ & $\begin{array}{l}1.59 \\
1.71 \\
0.89\end{array}$ & $\begin{array}{r}184 \\
63 \\
-30\end{array}$ & $\begin{array}{l}0.54 \\
0.51 \\
0.74\end{array}$ & $\begin{array}{l}0.11 \\
0.14 \\
0.41\end{array}$ \\
\hline $\begin{array}{l}5-1 \\
5-2 \\
5-3 \\
5-4 \\
5-5\end{array}$ & $\begin{array}{l}0.5 \\
" 1 \\
" 1 \\
"\end{array}$ & $\begin{array}{l}612 \\
598 \\
441 \\
178 \\
332\end{array}$ & $\begin{array}{r}143 \\
143 \\
137 \\
77 \\
115\end{array}$ & $\begin{array}{l}25.5 \\
26 \\
34 \\
47 \\
38\end{array}$ & $\begin{array}{r}* 140 \\
138 \\
* 141 \\
* 60 \\
* 84\end{array}$ & $\begin{array}{l}1.02 \\
1.04 \\
0.97 \\
1.28 \\
1.37\end{array}$ & $\begin{array}{r}250 \\
246 \\
177 \\
81 \\
158\end{array}$ & $\begin{array}{l}2.45 \\
2.43 \\
2.50 \\
2.19 \\
2.11\end{array}$ & $\begin{array}{r}110 \\
108 \\
36 \\
21 \\
74\end{array}$ & $\begin{array}{l}0.29 \\
0.29 \\
0.28 \\
0.37 \\
0.40\end{array}$ & $\begin{array}{l}0.65 \\
0.65 \\
0.14 \\
0.28 \\
0.18\end{array}$ \\
\hline $\begin{array}{l}3-1 \\
3-2 \\
3-3\end{array}$ & $\begin{array}{l}0.3 \\
* \\
*\end{array}$ & $\begin{array}{l}632 \\
492 \\
182\end{array}$ & $\begin{array}{l}58 \\
54 \\
10.5\end{array}$ & $\begin{array}{l}22 \\
27 \\
14\end{array}$ & $\begin{array}{l}* 135 \\
* 119 \\
* 54\end{array}$ & $\begin{array}{l}0.43 \\
0.46 \\
1.95\end{array}$ & $\begin{array}{l}208 \\
163 \\
120\end{array}$ & $\begin{array}{l}3.04 \\
3.02 \\
1.52\end{array}$ & $\begin{array}{l}73 \\
45 \\
66\end{array}$ & $\begin{array}{l}0.12 \\
0.13 \\
0.56\end{array}$ & $\begin{array}{l}0.11 \\
0.14 \\
0.33\end{array}$ \\
\hline
\end{tabular}

Note: *=the Velocity between the Bottom and the Middle Position of the Pipe, and $\varphi^{\prime}$ is calculated by Yagi's Formula,

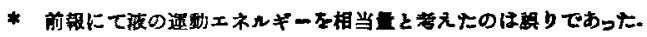


おる。また各相のビストン状の長さは流量が大きくなる につれて長くなるらしいことが写真から観察された。

最後に Hold up 6 を测定值より求めた赫果を Table 3 にのせてある。矢木氏2〉の実験式より求めたののは $\varphi^{\prime}$ として同表水してある。これらは互にかなり相違して いるが，矢木氏らの夷歌籍囲はややエア，リフト，ボン プの使用箱用とは異なるし，塩水法の值は殿間的なるの て平均値を示さねから一致しなくても不当ではない。

\section{V 結 論}

各租の液体にエフ、ソフト，ボンブを使用してみた結 果隹，特に粘性が大きいときや相当量の固体粒を含むと きは大洗量に批いて性能が著しく低下し，小流量では粘 性がきいと却って性能向上が汉られる他は水の場合と 注とんと变らない性能を示す。すなわり夜体の物理的性 面には比較的鈍感な装置である。次洁果の概要を列举 万る。

1. 表面裖力は $35 \sim 80($ dyne $/ \mathrm{cm})$ の範囲でははと んと影響がない。

2. 粘性の影響は大流量で性能を低下させ，小流量で 性能向上を示すが，普通使用されるべき最適流量から最 大液量附近までは同一空気量に対し大体次式が成立す ろ。

$$
Q \infty \mu^{-0.25}, \quad(0.01<\mu<0.4 \text { poise })
$$

3. 比重の影璄は1.0〜1.2の範囲ではあらわれない。 ただし液量を容磧で示した性能について論した場合であ る。

4. 固体粒を多量に含む三相流のときは性能は著しく 低下する。

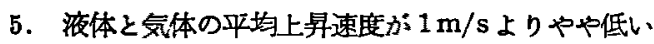
所で最適点（好率最大）を示し， $2 \mathrm{~m} / \mathrm{s}$ 程度で最大液量 点となることが，おらゆる場合についていえる。

6. 埴水法炕よる slip の測定結果性最適点で $0.5 \mathrm{~m} / \mathrm{s}$ 以下, 最大液量点で $1 \mathrm{~m} / \mathrm{s}$ 程度となった。

感謝： 実検用材料を恵与していただいた東亚合成名 古屋工場, 東洋プライウッド, 日本碍子, 名古屋市水 道同净水嚗，呿上び実鈳上の便宜を永年月に亘り与年 て下さった本学水力実験窒に厚く御礼申上げるととも に，本実祫のおのおの一部分を分担協力してくれた野 口泰久，坂茂，およひ溉井清祐の諸君に感謝する。

\section{Symbols :}

o: Submergence $=(l-h) / l$

$d$ : Dia. of Air Lift Pipe, $\quad(\mathrm{mm} \phi)$

$l$ : Length of the Pipe, (mm)

$h$ : Head of Lift, (mm)

$Q$ : Volume of Lifted Liquid, $\quad(c c / s)$

$Q_{0}$ : Volume of Lifted Water, (cc/s)

$V_{0}$ : Air Volume at Atmospheric Pressure,

$Q / Q_{0}:$ Ratio of Lifted Volume

$G$ : Weight of Lifted Liquid with Solid Particles,

$\eta$ : Efficiency of Air Lift Pump

$$
=100 \rho Q h /\left\{P_{0} V_{0} \ln \left(P_{0}+\rho h\right) / P_{0}\right\}
$$

$\rho$ : Density of Liquid, (g/cc)

$P_{0}:$ Atmospheric Pressure, $=1033\left(\mathrm{~g} / \mathrm{cm}^{2}\right)$ or (cm Aq.)

$\boldsymbol{\mu}$ : Static Viscosity of Liquid, $(\mathrm{g} / \mathrm{cm} \cdot \mathrm{s})$ or (poise)

$\mu_{0}$ : Static Viscosity of Water,

$$
\text { (g/cm.s) or (poise) }
$$

$v_{w}$ : Liquid Velocity in the Pipe, measured by the Salt Water (Electrical) Method,

$A_{20}$ : The Portion of the Sectional Area of the Pipe, which is occupied by Liquid,

$$
\left(\mathrm{cm}^{2}\right)=Q / v_{\text {w }}
$$

$A_{a}$ : The Portion of the Pipe Section, occupied by $\mathrm{Air},\left(\mathrm{cm}^{2}\right)=A-A_{\imath 0}$

$v_{a}$ : Air Velocity in the Pipe, $(\mathrm{cm} / \mathrm{s})=V_{0} / A_{a}$

$A$ : Sectional Area of the Pipe,

$$
\left(\mathrm{cm}^{2}\right)=\pi d^{2} / 4
$$

$$
\begin{aligned}
& (\mathrm{cm} / \mathrm{s})=v_{a}-v_{2 b} \\
& =A_{20} / A
\end{aligned}
$$

\section{Literature Cited :}

1) Chem. Eng. (Japan) 16, 111 (1952-4)

2) Yagi S., Shirai T., Sasala T.: Chem. Eng. (Japan), 15, 317, (1951-7)

3) Yagi S., Kato. Y.: Chem. Eng. (Japan), 18, 2, (1954-1)

4) Yagi S., Sasaki. T. : Chem. Eng. (Japan), 17, 216, $(1953-6)$

5) Ishigaya S., et al.. . Trans. Japan Society of Mechapical Engineers, 18, No. 72, 31, (1952) 


\title{
Characteristics of the Air Lift Pump for Various Liquids.
}

\author{
Koichi Iinoya and Norio Kimura.
}

The characteristics of the air lift pump for water under various conditions have been previously reported. During the past three years many experiments have been conducted with this pump relative to the use of many kinds of steel and glass pipes for soap suds, light oil, spindle oil, ammonium sulphate solution, muddy water, sandy water and wood powder water. The effects of physical properties of liquids on the characteristics of this pump have shown that the pump is nonsensitive to these properties on the whole.

The main experimental results are as follows :

1) Effects of surface tension between 35 and 80 dyne/cm are negligible. (Fig. 1)

2) Effects of specific density between 1 and $1.2 \mathrm{~g} / \mathrm{cc}$ are also negligible, if lifted quantity of liquid is expressed by volume. (Fig. 1,6 \& 7 )

3) Static viscosity makes lifted quantity decrease at larger flow quantity, but rather improves the characteristics at smaller flow. In the usual region between the optimum point (the max. efficiency) and the maximum liquid point, the next formula is obtained. (Fig. 2 5).

$$
Q / Q_{0}=\left(\mu / \mu_{0}\right)^{-1 / 4}
$$

where $\quad 0.01<\mu<0.4$ poise, $(\mathrm{g} / \mathrm{cm} . \mathrm{sec})$

4) The characteristics of three phase flow, which contains solid particles, are inferior. (Fig. 6, 7)

5) Mean lifted velocity $v_{m}=\left(Q+V_{0}\right) / A$ is a little lower than $1 \mathrm{~m} / \mathrm{s}$ at the optimum point, and is about $2 \mathrm{~m} / \mathrm{s}$ at the maximum liquid point in all cases.

6) Instantaneous slip velocities between liquid and air are obtained by the salt water (electrical) method, and the slip is below $0.5 \mathrm{~m} / \mathrm{s}$ at the optimum point and about $1 \mathrm{~m} / \mathrm{s}$ at the maximum point. (Table 3 )

例えば合莱氐の“蛪汼に 関する交献”（本誌 18 巻 9 号）御镜下さい。1951年よ り1953年までにあらかれた最 故重要士交献の大部分か Rushton К上るものてある ととに算かされます。とれる の研究によって彼は1952年度 の W.H. Walker 黄考授 られました。

\section{J. Henry Rushton}

\begin{tabular}{|c|c|}
\hline Pennsylvania 大学抽よび & の最高権威でありますが，ま \\
\hline その大学院を卒業して, 数年 & た Rochester にある復汼器 \\
\hline 間を工場で湖いた Rushton & 械の会社の研究所長を莱ねて \\
\hline はマの後数滳に移り，Drexel & いる。 \\
\hline $\begin{array}{l}\text { 大学, Michigan 大学, Vir- } \\
\text { ginia 大学を維 } \text { I Illinois I }\end{array}$ & 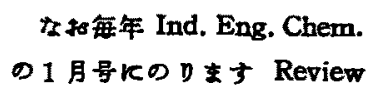 \\
\hline 業大学の教授をな & К枕いては "Mixing"の項 \\
\hline 至っています。 & 目て担当しているてとる御承 \\
\hline 构 50 K据よs & 知のととと思い亡す。 \\
\hline CD研究諭文 & \\
\hline
\end{tabular}

